Hydrol. Earth Syst. Sci. Discuss.,

https://doi.org/10.5194/hess-2019-598-AC1, 2020

(c) Author(s) 2020. This work is distributed under

the Creative Commons Attribution 4.0 License.
Hydrology and

\title{
Interactive comment on "Multi-variable,
}

multi-configuration testing of ORCHIDEE land surface model water flux and storage estimates across semi-arid sites in the southwestern US" by Natasha MacBean et al.

Natasha MacBean et al.

nlmacbean@gmail.com

Received and published: 9 April 2020

The comment was uploaded in the form of a supplement:

https://www.hydrol-earth-syst-sci-discuss.net/hess-2019-598/hess-2019-598-AC1-

supplement.pdf 